\title{
Thuggee in England: Tracing the Origin and Development of Fantasies of Thug-Invasion and Reverse Colonization in late nineteenth century British Fiction
}

\author{
Ayusman Chakraborty, PhD \\ Assistant Professor of English (W.B.E.S.). Taki Government College, \\ hinduayusman@gmail.com, ORCID: oooo-0003-0641-0652
}

\begin{abstract}
A lot has been written on Thuggee and nineteenth century British operations against it. Instead of delving directly into either of these two well investigated areas of research, this paper seeks to chart how several nineteenth century British writings exhibit a curious fear of Thug infiltration. Keeping in their minds some actual instances, early British colonial officials worried about the Thugs joining government services under them to survive and sabotage the anti-Thuggee campaign. This paper argues that this apprehension gradually developed into the fantasy of being reverse colonized by the Thugs. Late Victorian writers of fiction fantasized the Thugs invading England, or, what must have been more unnerving to them, converting the Britons themselves to Thugs. Using unpublished official records and literary works as sources, this paper tries to map how colonial anxiety of 'Thug infiltration' originated and later grew into the fantasy of reverse colonization by the Thugs. It also tries to link this to specific historical developments in that period.
\end{abstract}

Keywords: Thuggee, Thug infiltration, Thug immigration, invasion, Reverse colonization, British female Thugs.

\section{Introduction}

Thuggee as a peculiar brand of criminal homicide has received sufficient attention from scholars. So have nineteenth century British operations against it. Instead of concentrating directly on either of these two well scoured fields of investigation, this paper explores how the Thugs made the colonizing British remain in a state of anxiety all through the nineteenth century. Early in the nineteenth century British colonizers in India were shocked to discover that some of their Indian subordinates in government services were Thugs in reality. This discovery caused enough consternation to make them lose some of their self-confidence. Arguably, behind such anxiety there lay the more potent dread of being outsmarted by the colonized subjects. This is probably why the British continued to fear the reappearance of the Thugs even after successfully suppressing Thuggee by the midnineteenth century. ${ }^{\mathrm{i}}$ This paper goes on to show that this fear of losing to the Thugs grew into fantasies of reverse colonization with the passage of time. Late nineteenth century British fictions, which imagine the Thugs threatening Britain itself, display such fantasies. Instead of dismissing such tales as products of the febrile imagination of the colonizers, it

(c) AesthetixMS 2021. This Open Access article is published under a Creative Commons Attribution Non-Commercial 4.0 International License (http://creativecommons.org/licenses/by-nc/4.o/), which permits non-commercial re-use, distribution, and reproduction in any medium, provided the original work is properly cited. For citation use the DOI. For commercial re-use, please contact editor@rupkatha.com. 
is more fruitful to study how the anxiety of 'Thug infiltration' originated and grew into fantasies of Thug invasion and reverse colonization in the nineteenth century.

To trace how the fear of 'Thug infiltration' originated and grew into the anxiety of reverse colonization, this paper draws upon both unpublished official documents and published works belonging to the nineteenth century. By 'Thug infiltration' I mean the idea that the Thugs purposefully joined government services to outwit their colonial persecutors and survive British anti-Thuggee campaign. In time, this developed into the fantasy that they could invade Britain itself to harm its inhabitants and acculturate some of the Britons. Through study of official documents, it is revealed how the anxiety of Thug infiltration had its root in actual experiences of colonial officials in India. However, the fear of Thug invasion is entirely imaginary. It can be found only in literary works and not in any official document. A survey of some mid-nineteenth century novels featuring the Thugs allows us to trace how fantasies of Thug invasion and reverse colonization gradually evolved out of the basic fear of Thug infiltration. The article offers an explanation for the emergence of these fantasies in late nineteenth century British literary works by linking these to some specific political developments occurring concurrently in India at that period. Finally, specific expressions of such fantasies in some late Victorian fictions are highlighted by way of illustration.

Without a brief introduction to Thuggee, understanding the matter under consideration would perhaps become difficult. Therefore, the next section begins with a short sketch of Thuggee before moving on to the main issue.

\section{From Infiltration to Invasion and Reverse Colonization: Origin and Development of British Anxiety}

Was Thuggee real, a discursive construction, or misrepresentations of an actual practice? The answer might not be readily forthcoming. This is because, as Tom Lloyd points out, "no source on 'thuggee' offers a window on the past; a transparent, unobstructed view of "what happened"' (Lloyd 2006, 6). Instead of trying to suggest any answer to the question mentioned above, this paper concerns itself only with colonial perspectives on Thuggee. The early colonial authorities conceptualized Thuggee as a synthesis between highway robbery and murderous cult. As they described, it involved gangs of highly organized criminals robbing and murdering travellers on the road by following a particular modus operandi. These Thugs inveigled travellers to accompany their gangs before they murdered and robbed them at a convenient spot. They left few survivors, and usually took care to inter the corpses to prevent detection. Their preferred weapon was the noose or phansi, though they occasionally used conventional weapons like swords and poisons (see for instance Singha 1993, 101; Wagner 2014, 119). The colonizing British believed that, despite their differences in religious beliefs and practices, both Hindu and Muslim Thugs worshipped Goddess Kali in common as their patroness. It was also assumed that the victims were offered as sacrifices to the Goddess. The first offensive against the Thugs was launched by British colonial officers as early as in 1810 (Wagner 2014, 53). However, it was 
Major-general Sir William Henry Sleeman (1788 - 1856) who successfully brought Thuggee to public attention. He spearheaded the campaign against it. Under his aegis, the Thuggee Department was established in 1835. It was rechristened Thuggee and Dacoity Department in 1839 (ní Fhlathúin 2001, 82). Harsh measures were adopted to eradicate Thuggee. Wagner mentions that between 1826 and 1835, a total of 1562 Thugs were caught and tried (Wagner 2014, 228). Because of the severity of the measures adopted, Thuggee almost became extinct by the middle of the nineteenth century. ${ }^{\text {ii }}$

During the years of intense campaign against Thuggee, British authorities naturally worried about the Thugs managing to evade arrest. One can only imagine how anxious they must have felt when they discovered that some of their Indian subordinates and associates were Thugs in reality. Such cases were not really very rare. In Ramaseeana, Sleeman records the famous Thug leader Feringeea claiming that he used an alias to work as a leader or jemadar of the hurcaras (the postmen) under General David Ochterlony (Sleeman 1836, 236). In a letter dated $28^{\text {th }}$ November 1832 , the Court of Directors mentions that "cases have been not very infrequent in which these people [Thugs in government services] have been enabled to the purposes of their horrible occupation the opportunities afforded by public employment." In fact, they cite a particular case where one Indian police officer in British service, "who was actually sent in search of a Thug", used that very opportunity to go on a Thug expedition himself. When this man was caught on the first occasion, he successfully freed himself and his whole gang by simply mentioning his official rank to the pursuers. The letter further mentions, "Two other police officers of inferior rank formed part of the same gang" (Letter from the Court of Directors 1832). iii Fanny Parkes mentions another case in her memoir. She writes that she had witnessed the execution of a chaprasi in 1832, whom the government had sent to apprehend a gang of Thugs but who "joined himself with them and by his presence protected them" (Parkes 2002, 121). Naturally, such occurrences eroded, at least to some degree, the colonial officials' self-confidence. They became alarmed enough to fear that the Thugs might intentionally join government services to survive and even sabotage British anti-Thuggee campaign. This was the anxiety of 'Thug infiltration'. ${ }^{\text {iv }}$ Quite naturally, it finds expression in some literary works of that period. In Confessions of a Thug (1839), one finds the former Thug Soobhan Khan serving the unsuspecting British as a jemadar or leader of the government peons. As Khan himself points out, he uses his position as a government servant to assist the Thugs: giving them information and putting in "a kind word now and then with the Sahib-logue" for them (Taylor n.d., 211). Soobhan also obtains a forged document of identification from English officers for the Thug-protagonist Ameer Ali (Taylor n.d., 212). Here we have a Thug who entered government service only to dupe the government. ${ }^{v}$ In recounting the roguery of Soobhan Khan, the novel obviously reflects the anxieties of many of the author's contemporaries and compatriots in India. For this reason, I agree with Javed Majeed's assessment that the novel does not construct "the British in India as a masterful, unifying, and enabling presence" (Majeed 1996, 98). Behind the façades of dominance and mastery, colonial insecurities seep out of this text.

The fear of 'Thug infiltration' is best expressed in a curious short story entitled "Adventure with a Thug: An Old Officer's Story" by an anonymous author. It was published 
in Reynolds's Miscellany in 1866. The story narrates how the Thug leader Runjheet entered the unnamed narrator's service under a Muslim alias to assassinate him. He did this because the narrator, "a colonel of cavalry" in charge of the "district of Benares", had earlier destroyed one of their towns and even desecrated a Kali temple (Anonymous 1866, 388). Though a Thug named Ranjeet was really apprehended by Captain Borthwick in April 1828 (List 1829-36), this story is in all probability a fictitious account. This is because the historical Ranjeet was not killed, as we find in the end of this story. His name appears in a list of approvers, showing that he survived to become one. ${ }^{\mathrm{vi}}$ Moreover, in the colonial setting, the news of a Thug joining government service to assassinate a British officer would have caused enough consternation to receive wide publicity. But to my knowledge, no mention of this event occurs either in any official document or in any other newspaper. Fiction or otherwise, this tale reveals the basic insecurities of the early colonial administrators who feared betrayal by their Indian underlings. Equally unsettling to them was the probability of Thuggee surviving all their attempts to eradicate it.

In this context, it is interesting to note that British administrators in India continued to worry about the Thugs almost till the very end of the British Raj. This was even when they had eradicated Thuggee much earlier. For instance, in 1933 Sir George MacMunn claimed that the bomb parasat or "bomb-worshipping" Indian revolutionaries were spiritual descendants of the Thugs (MacMunn 1933, 219). It becomes obvious from his words that he considered Thuggee and militant Indian nationalism to be two different embodiments of the same evil 'Indian' propensity for violence and bloodshed. MacMunn writes:

The stories of modern Bengal secret murder cult and the Babbar Akali movement ... are tinged with the same fervour that animated the darkest side of Thuggism (sic). And it is just this presence of some ancient horror, existing beneath the outer surface of perfectly reasonable political aspirations, which has been a source of trouble to many a kind Viceroy desiring only India's good (MacMunn 1933, 218) [emphasis mine].

Conceptualized as a propensity instead of a type of crime, Thuggee could be made to appear as ancient and ineradicable. MacMunn and the like-minded colonizers lifted Thuggee out of its original context of highway crime to present it as one of the manifestations of the innate depravity' of the Indians. Unsurprisingly, colonial writers, particularly metropolitan writers in England, continued to fear its reappearance. Here one must recall that the metropolitan writers lacked first-hand knowledge of Thuggee and relied entirely on the British expatriates for their information on it. In other words, relying almost entirely on hearsays, they often disregarded or ignored actual facts. As our readings will show, some of them doubted that Thuggee could ever be eradicated. Even when the colonial government claimed victory over it, these writers feared that Thuggee was only lying dormant and would re-emerge if British vigilance was slackened. It seems that this belief in the indestructible nature of Thuggee owed its origin, at least in part, to Captain Philip Meadows Taylor's Confessions of a Thug. In this novel, the Thug-protagonist Ameer Ali boasts with 
confidence, "Thuggee, capable of exciting the mind so strongly, will not, cannot be annihilated" (Taylor n.d., 1). To the metropolitan writers, Taylor's novel, rather than factual records and documents, formed the main source of information on Thuggee. ${ }^{\text {vii }}$ Naturally, they believed whatever was written in it and did not take the trouble to cross-check the information. Interestingly, unlike some of his contemporaries and subsequent writers, Taylor himself did not decontextualize Thuggee. We may note that Amir Ali repeatedly uses the words "occupation" and "profession" to describe Thuggee (Taylor n.d., sic passim). Again, in his article "State of Thuggee in India", Taylor defines Thuggee as "a system of crime" which "derives even a sanction from superstitious motives of religion" (Taylor 1843, 246). It is clear from his choice of words that he sees it primarily as a type of crime which drew its approval from (Hindu) religion. It is to be noted that Taylor himself participated in British campaigns against Thuggee, as he mentions in his autobiography (Taylor 1878, 72-73). He definitely knew the subject too well to develop fantastic views on it. It was Eugène Sue's novel Le Juif Errant (1844), translated into English as The Wandering Jew, which taught later writers to decontextualize Thuggee in order to rant at religious beliefs and customs of the Indians. Sue entirely ignored the criminal aspect of Thuggee and overemphasized its association with religion. His Thugs form a "homicidal sect" - "the brothers of the good work" - who sacrificed human beings only to please their Goddess and accrue merit in the afterlife (Sue 2016, n.p.). Sue writes that the Thugs, "killed without motive, without passion-killed for the sake of killing-for the pleasure of murder-to substitute death for life-to make of a living man a corpse" (Sue 2016, n.p.). Thus from a crime seeking its approval in (Hindu) religion and Goddess worship, Thuggee, in Sue's rendering, became a religion in itself. As we shall find, the later English writers all followed him in imagining Thuggee as a 'barbaric' religion whose practitioners were required to murder indiscriminately as part of their religious observances. In the process, Thuggee's actual nature as highway banditry was almost entirely ignored. Sue was also responsible for introducing the trope of the Thug-immigrant who travelled to Europe to harm its inhabitants. In The Wandering Jew, the Anglo-Indian "half-caste" Thug leader Faringhea (loosely modelled on the renowned Thug leader Feringeea) runs away to Europe to evade arrest. In Europe, he enters into the service of corrupt Jesuit priests, reasoning that both the Jesuits and the Thugs have the common goal of destroying human life. Becoming the mouthpiece of the novel's anti-Jesuit polemics, he declares, "Rome and Bowanee (sic) are sisters" (Sue 2016, n.p.). Besides expressing anxiety about Thug-immigration, Sue's novel introduces some other ideas which would reappear in later works. These are, namely, distrust of Eurasians or "half-castes" and the fear of Europe being invaded by the Thugs.

It appears that in the mid-nineteenth century Continental European writers of fiction took more interest in Thuggee than their British counterparts. We may note that for a long time Meadows Taylor's Confessions of a Thug remained the only British fiction to depict Thuggee. Though a handful of scholars like David C. Rapoport believe that William Wilkie Collins' novel The Moonstone (1868) depicts the Thugs (Rapoport 1984, 661), there is little in the text to support this view. Likewise, Wendy S. Jacobson has convincingly challenged the assumption that Dickens wanted to introduce Thuggee and the Thugs in his unfinished 1870 novel The Mystery of Edwin Drood (Jacobson 1977, 526-37). 
Thus, barring one or two insignificant exceptions, almost no British writer of fiction took up the topic before the 188 os. On the other hand, Thuggee continued to appear, or at least find mention, quite frequently in mid-nineteenth century European novels. Besides Sue's The Wandering Jew, mid-nineteenth century European novels featuring Thuggee or the Thugs include Hermann Goedsche's Nena Sahib, oder: Die Empörung in Indien (1858-59), René de Pont-Jest's Le Procès des Thugs (1877) and Jules Verne's Le Tour du Monde en Quatre-vingts Jours (1872) and La Maison à Vapeur (1880). viii Curiously, British writers of fiction suddenly started taking interest in the Thugs in the last two decades of the nineteenth century. There is something odd in their remembering Thuggee so late, when it ceased to remain a problem even in India. More strangely, in the works of these authors, Thuggee invades Britain. Either the Thugs immigrate to England or the British themselves become Thugs. In either case, it is the Britons who are found to be in peril and not the Indians. Of course, there is no record of any Thug ever travelling to England to practice Thuggee there. Nor do we find any record of any Englishman or Englishwoman turning into a Thug. In fact, contrary to the fear expressed in these latter writings, many early British expatriates in India were convinced that the Thugs never preyed upon the Europeans (see, for instance, Parkes 2002, 93). ${ }^{\text {ix }}$ As for the Thugs immigrating to England, the early expatriates simply did not imagine such a possibility. Then, why did later British writers started worrying about Thuggee or the Thugs invading Britain only after the 188 os? Why not before this period? As I find, reappearance of Thuggee in British fiction coincided with the growth of the fear of reverse colonization in late Victorian Britain. All these later tales featuring the Indian Thugs are what Stephen D. Arata calls "reverse colonization narratives". In such stories, a "terrifying reversal" occurs and "the colonizer finds himself in the position of the colonized" (Arata 1990, 623). Arata points out that reverse colonization narratives expose the colonizers' self-doubt. He links this to Britain's loss of fortune and decline in global influence in the late nineteenth century (Arata 1990, 622). Since the anxiety of the Thugs invading Britain had no factual basis, the colonizers' erosion of selfconfidence in the late Victorian period provides the only explanation for it. As far as India is concerned, one may remember that the last three or four decades of the nineteenth century were the formative years for modern nationalism in India. There were agitations over the Vernacular Press act in 1878, followed by the Ilbert Bill Controversy in 1883, and the foundations of the Indian National Conference in 1883 and the Indian National Congress in 1885 (Majumdar, Raychaudhuri \& Datta 2010, 880-83). At this period, the colonizing British became increasingly aware of the Indian subjects' demand for greater participation in the governance of India. They naturally feared that the Indians might infiltrate colonial administration only to throw off the British yoke in due course. In a new setting, there was thus a return of the original fear of the colonized subjects joining government services only to best their colonial masters. It is an interesting fact that later British fictions featuring the Thugs were all published after the 188 os. Chronologically, these are Kalee's Shrine (1886), "Uncle Jeremy's Household" (1887), A Fatal Affinity: A Weird Story (1889) and "The Thug's Legacy" (1910). It may not have been a mere coincide that these were all written and published after the Ilbert Bill Controversy. Introduced by Sir Courtenay Peregine Ilbert, the Bill called for the withdrawal of a privilege till then enjoyed by European expatriates in India. This was the privilege of being judged by one of their 
compatriots in a lawsuit. In other words, the Bill sought to empower senior Indian magistrates to try European expatriates in India (Majumdar, Raychaudhuri \& Datta 2010, $880-81$ ). Most British expatriates found this entirely unacceptable. What they actually dreaded was the prospect of being governed or controlled by those whom they had ruled for so long. In a way, to them this must have appeared as something akin to reverse colonization. Moreover, there is also the return of the fear of being outsmarted by the colonized. As I see it, the situation in India after the 1880 os must have reminded many British people of the earlier fear of the Thugs' joining government services. We need to keep in mind that the British lost most of their interest in Thuggee by the mid-nineteenth century because it was almost extirpated by the 1850 os and ceased to remain a source of concern. It was only when the Indians started joining the civil services in higher ranks, and thereby implicitly threatened British hegemony, that the British authors remembered the Thugs who, in their view, had (tacitly) challenged their governance in the past. ${ }^{x}$

It needs to be admitted here that we do not have enough evidence to establish that all these works were written in direct response to the Ilbert Bill Controversy. We may only demonstrate that these authors feared the colonized subjects besting their colonial masters. Since the Ilbert Bill Controversy provided an occasion for the articulation of the colonized people's demand for greater power, one may suppose that it may have been at the back of some of these authors' minds too when they wrote these works. Here we might also recall that mid-nineteenth century Continental writers had earlier imagined the Thugs threatening Europe. Besides Sue's novel, this idea appears in the second part of René de Pont-Jest's Le Procès des Thugs. Here Nadir, the son of Feringhea, immigrates to England to plague the British (for a reading see, Woerkens 2002, 273). Likewise, in his novel Cord and Creese (1869), the Canadian author James De Mille had written about an English criminal who associated with the Thugs. Most likely, these tropes of invasion and reverse colonization were borrowed by late nineteenth century British writers from these earlier works. But even if this is exactly the case, it still does not explain why they came to employ these tropes predominantly after the 188 os and not before that period [emphasis mine]. As I suggest, the return of the fear of being outwitted by the colonized alone explains this conundrum. ${ }^{\mathrm{xi}}$

Brief analyses of some late nineteenth century British fictions will reveal how these combine fears of Thug invasion and reverse colonization. For instance, Kalee's Shrine, written by Grant Allen and May Cotes, expresses these anxieties. This novel is, what Patrick Brantlinger calls, an Imperial Gothic - having for its themes "individual regression or going native" and "an invasion of civilization by the forces of barbarism or demonism" (Brantlinger 1988, 230). The female Anglo-Indian ${ }^{\mathrm{xii}}$ protagonist Olga Trevelyan is ordained a Thug in her infancy by her Indian nanny (ayah) Gungia with the help of the Thug-priest Girjee. By making her a Thug, the ayah intended to forge an unbreakable mystic bond with her beloved ward who was soon to be taken from her and sent forever to England. As part of the initiation ritual, the priest severs two of Olga's optic nerves which make it impossible for her to close her eyelids during sleep. Olga grows up in England. While holidaying in a coastal town, she meets and falls in love with the oculist Alan Tennant. She is a 
somnambulist and is apparently possessed by Goddess Kalee [Kali] in her sleep. Trouble befalls, when she strangles her cousin Nora Bickersteth under a hypnotic trance induced by a professional mesmerist for entertainment. A superstitious retired Anglo-Indian officer named Sir Donald Mackinnon had long suspected Olga of being initiated into Thuggee in her childhood. He now becomes convinced of her guilt. However, Alan Tennant successfully defends his lover, pointing out that she merely acted under hypnotic trance. As the authors put it, "There was no Kalee! There had never been a Kalee! There could be no Kalee!" (Allen and Cotes n.d., 179). By stroke of luck, Nora survives and things end well for Olga and Alan. The novel reveals how British understanding of Thuggee transformed over time. To Allen and Cotes, Thuggee was a "religion" whose votaries worshipped "nobody but the goddess Kalee" (Allaan and Cotes n.d., 19). Though they mention that the Thugs indulged in highway banditry, they also write that they offered blood of their human victims "in a bowl on the altar of their goddess" (Allen and Cotes n.d., 19). As one may note, this is a purely imaginary rendering of Thuggee. The Thugs did claim worshipping Goddess Kali, but not to the exclusion of every other deities. The Muslim Thugs, for instance, maintained that they worshipped Allah as pious Muslims - Bhavani or Kali being only worshipped before Thug expeditions as the patroness of their profession (Sleeman 1836, 145-46). Moreover, no official document ever mentions their offering the blood of their human victims in a bowl to Goddess Kali! xiii Their initiation ritual never involved severing optic nerves of the apprentices. But the most fantastic idea is that of a British girl transforming into a Thug, even if only unconsciously. Olga's transformation is meant to show that even the British were capable of 'regressing' into a 'primitive' state:

A terrible change had come at once over her voice and countenance. It was no longer Olga - their gentle, soft-souled Olga, that spoke: it was the low suppressed implacable murmur of a human tigress (Allen and Cotes n.d., 102).

This, one may recognize, reflects the anxiety of 'going native' or succumbing to one's primitive nature through contact with the colonized. One may also detect the fear of Thuginvasion and reverse colonization in the novel. We may remember that Olga was actually ordained a Thug in her infancy. That is, she was (forcefully) acculturated. With her, Thuggee travels to England. The novel hints that she suffers from split personality disorder, with Kali being one aspect of her personality. During the reverse hypnosis session to undo the effects of the former one, Olga converses with and overcomes this Kali-persona within herself (Allen and Cotes n.d., 189-9o). Thus, going by the novel's reasoning, Thuggee infiltrates British society through Olga. It reverse colonizes the British girl who becomes a female Thug, if only unconsciously.

In Sir Arthur Conan Doyle's short story “Uncle Jeremy's Household”, we once again come across a female Thug who is partly British. Female Thugs, though known, were not very common even in India (see Chakraborty 2020a, 79-91). The imagining of Eurasian and British women in the role of Thugs in these tales therefore appears surprising. Probably, this developed from the age-old patriarchal idea that women, being less rational, were more susceptible to evil influences. For instance, the seventeenth century cleric and witchhunter Francesco Maria Guazzo mentions in his Compendium Maleficarum (1608) that, 
"since women have less power of reasoning and less wisdom, it is easier for the devil to delude them ..." (Guazzo 1988, 137). Since by this time Thuggee was seen as an evil 'religion' almost akin to Satanism, the authors may have had the idea in mind that the (irrational) white females were more vulnerable to its 'evil' influences than the (rational) white males. ${ }^{\text {xiv }}$ In Doyle's story, the narrator Hugh Lawrence discovers, while staying with his friend and his uncle in their country house, that the attractive Eurasian governess Miss Warrender is in reality a Thug princess. She is the daughter of the semi-independent Thug chieftain Achmet Genghis Khan who lost his estate and life for participating in the Sepoy Mutiny of 1857. Lawrence also discovers to his horror that Uncle Jeremy's villainous secretary $\mathrm{Mr}$ Copperthorne intends to use Miss Warrender against her will to murder Uncle Jeremy. However, justice overtakes Copperthorne when he is strangled by one of Miss Warrender's Indian 'subjects'. She disappears from England with her Thug associate, presumably to return to India (Doyle 2012). Yumna Siddiqi correctly points out that the story reflects Doyle's mistrust of Eurasians and miscegenation. She also maintains that the story "point to specific anxieties about the governability of subjects of the British Empire" (Siddiqi 2008, 57). While agreeing in the main with this analysis, I call the readers' attention to the more immediately recognizable anxiety about Thug infiltration in this story. Two things are to be kept in mind. First, the story contends that in failing to control her murderous impulses, Miss Warrender lets her 'Indian nature' dominate over her British one. At the end, it is implied that she gives up her English heritage and Christian faith altogether to embrace Thuggee and Kali worship. There is thus a successful reverse acculturation in her case. Secondly, the story contends that the British have failed to eradicate Thuggee, and "it flourishes far more than the authorities suppose" (Doyle 2012, n.p.). It assumes that the extinction of Thuggee, through the spread of the Gospel, is, at best, a thing to look forward to in the future. Given that Thuggee was fully eradicated by the time this work was written, this is an anachronistic claim to make. Doyle had no actual reason for doubting British success in eliminating Thuggee. This appears more than an anxiety about governability. The story reflects the fear of failing to acculturate the colonized, and being dominated and acculturated by them instead.

The fear of Thug invasion is expressed more directly in Stuart C. Cumberland's $A$ Fatal Affinity: A Weird Story. Published in 1889, this work was surely inspired by the Whitechapel murders (1888-91) most of which were attributed to the infamous serial killer Jack the Ripper. Jack's victims were all women. So are the victims of the killer in this tale. However, unlike Jack, Rām Dass, the killer in this tale, does not randomly choose his victims. He is a wizard who belongs to a clique of Hindu black magicians called "Brothers of Darkness". They are required to kill at least thirteen souls a year, "as a part of their compact with Siva the Destroyer" (Cumberland n.d., 140). These victims are required to be "young, beautiful in mind, pure in body, and virgin in soul". The last point means that these are souls who have never reincarnated before (Cumberland n.d., 140). Rām Dass attacks them in his astral form with a magical dagger, which makes it impossible for anyone to see or apprehend him. Notably, Cumberland does not directly identify these wizards as Thugs. Nor is there any particular reference to Kali worship in this novel. Instead, the entire Hindu pantheon, with the exception of the creator God Brahma, is condemned as evil. However, 
the novel subtly associates these wizards with Thuggee. Colonel Mansfield, who saves the last victim of Rām Dass, had been formerly the "chief of the Thuggee and Dacoity Department" (Cumberland n.d., 38). It is his knowledge of India, and oriental white magic, which enable him to save his goddaughter Evelyn Hardcastle. Also, some Theosophists in the novel are shown to speculate that the murders were committed by members of "a band of modern Thugs" (Cumberland n.d., 91). It is obvious from these references that the author had the Thugs in mind when he wrote this novel. Interestingly, Rām Dass came to London with the ostensible purpose of studying "for the Bar" (Cumberland n.d., 88). The irony becomes clear to us once we remember that the colonizers launched their anti-Thuggee campaign apparently to restore law and order in India. Here a Thug-like murderer from India immigrates to London to study law, only to break it during his stay there. What could be a more perplexing case of 'Thug infiltration' - in its original sense! Obviously, Cumberland was worried about Indian lawyers studying English law to compete with the British themselves. He must have feared the Indian subjects defeating the colonial masters in their own game. His anxiety in this regard made him villainize an Indian lawyer in this novel.

Finally, we consider Francis Henry Atkins's story "The Thug's Legacy". This was published under his pseudonym Frank Aubrey in two instalments in English Illustrated Magazine. Atkins was a famous writer of pulp fiction. This story is a characteristic work of his. It is a fairly straightforward murder and mystery story. The only twist is that the murderer is empowered by an enchanted ring that once belonged to Thug chiefs. The ring bestows prodigious strength on its possessor, which allows him to effortlessly strangle to death even a strong man. It also makes the wearer more savage and ferocious. Robert Burton, the murderer in the story, confesses before his death that the ring gave him an "irresistible impulse or mania" to "strangle everybody who offended him" (Aubrey 1910b, 153). The contact with the colonized people, or their artefact in this case, thus changes the colonizer's nature. Burton's transformation into a homicidal criminal, through the influence of the ring, might thus be interpreted as an instance of reverse acculturation. Given that this jinxed ring with its potential of turning people to Thugs is taken from India to England, what actually occurs in this tale is reverse colonization by the Thugs.

Our study makes it clear that British anxiety of 'Thug infiltration' increased with the passage of time, instead of decreasing. This was to such a degree that the original fear of failing to curb Thuggee gave place to the fear of being subdued by Thuggee. Strangely, this happened despite the colonial government's actual success in suppressing Thuggee. Why did British colonizers come to fear something which they had successfully curbed much earlier? As already argued, only the colonizers' loss of confidence can explain this apparent inconsistency. The fear of being ousted from power by the colonized gave rise to fantasies of being dominated by the colonized. Because of this, in later British fiction the fantasy of Thug invasion came to stand for the actual fear of the Indian subjects infiltrating colonial government in India to challenge British rule. It is also to be noted that the later British writers conceptualized Thuggee primarily as a religion, and only secondarily as a crime. Imagined as a religion, it appeared capable of bringing at least some of the British people 
into its fold. Thus while the early British writers were only afraid of being outwitted by the Thugs in their efforts of eradicating Thuggee, the latter writers dreaded that Thuggee might invade Britain and acculturate the Britons themselves. It is basically their loss of confidence that made them fantasize in this manner.

\section{Conclusion}

In this paper, we have studied how late Victorian literature came to reflect the fantasies of Thug invasion and reverse colonization. But what was the actual impact of such fantasies on the minds of ordinary Britons? No direct answer is available to us. One may only note that the word thug has entered English vocabulary, suggesting significant impact of Thuggee on British minds. In this context, we may recall a recent article by Lallitha Joseph where she draws our attention to recent uses of the word in the United States of America. Undergoing semantic changes, thug has lost its original association with a type of (Indian) criminals, and has come to signify any violent person. But in contemporary America, there is an extensive use of the term to pejoratively label the underprivileged. Joseph draws our attention to contemporary applications of the word to label coloured dissenters in the United States. The purpose of this has been to delegitimize their dissenting voices (Joseph 2020). My paper shows that the Thugs have all along generated anxiety-ridden fantasies, where the privileged feared being outmanoeuvred and dominated by the aspiring underprivileged. It is curious to note how fantasies of Thug infiltration and invasion persist in our age, albeit articulated in different settings and contexts.

Finally, through study of fictional representations of the Thugs, this paper has shown how, from a crime drawing its sanction in religion, European literary imagination transformed Thuggee into a religion whose very essence was murder. This finding has wider implications. There are a group of scholars like David C. Rapoport who equate Thuggee with religious terrorism. Rapoport himself calls Thuggee "sacred" or "holy terror", and suggests that the Thugs murdered people only to please their deity (Rapoport 1984, 659 660). Though Alex Tickell has vigorously countered this view in his article "Excavating Histories of Terror" (Tickell 2010, 177-201), it may continue to find some support even after. The downsides of the understanding of Thuggee as a sort of religious terrorism is that, besides being based on selective reading, this idea could be used politically to justify and promote Hinduphobia or even Indophobia. ${ }^{x v}$ By revealing how the Europeans gradually imagined Thuggee as a 'murderous religion', this paper hopes to counter such malady in a little way. However, a full analysis of European construction of Thuggee is beyond the scope of the present paper. This is an area that calls for deeper probing in the future.

\section{Endnotes}


${ }^{i}$ The complete eradication of Thuggee was never formally claimed. But by the mid nineteenth century there was the feeling that victory over Thuggee had been achieved (Wagner 2014, 228).

ii For instance, one finds Captain H. M. Boddam reporting to Major Chas Hervey on $1^{\text {st }}$ July 1859 , "Thuggee by strangling is in Lower Bengal a thing of the past, except in some few but very rare occasions" (Boddam 1859). iii The unpublished reports of the Thagi and Dakaiti Department preserved at the National Archives of India carried no page numbers in their originals. Hence no page umber can be provided for these documents.

iv Till now, I have not been able to discover anything that might suggest that the Thugs purposefully entered government services to sabotage British anti-Thuggee campaign.

v One of the meanings of the Indian word thag, which forms the root of the English thug, is "a deceiver". Though he had formally given up practicing Thuggee, by deceiving his British employers, Soobhan Kahn seems to remain true to the principles of Thuggee all along.

vi Of course, we have to concede that there could have been several Runjheets/Ranjeets/Ranjits, as the name is very common among the Indians.

vii Sir Arthur Conan Doyle, for instance, openly acknowledges Taylor as the source in his short story (Doyle 2012, n.p.).

viii I leave out the novels of the famous Italian author Emilio Salgari, as they were published after the 188os. I also hesitate to include Francisco Luis Gomes' Portuguese novel Os Brâmanes (1866) in this list, because the writer, though a Portuguese M.P., was a Goan by birth.

ix The only exception was one Lieutenant Maunsell who was killed by the Thugs in 1812. For a description of the event, one can consult Wagner (Wagner 2014, 76-78).

${ }^{x}$ Unlike some scholars, I do not go so far as to propose that the Thugs were anti-colonial insurgents. I merely believe that the colonizing British saw them as threats to the colonial order. Later, they strategically evoked Thuggee to undermine Indian nationalism.

${ }^{x i}$ Why did European writers come up with this idea in the first place? This question is beyond the scope of this paper. I might just observe that a recent article suggests that the European non-British writers often invoked the continuing existence of Thuggee to point at the failure of British colonialism and 'civilizing mission' in India (Chakraborty 202ob, 11-12).

xii The word Anglo-Indian is used throughout this paper in its nineteenth century sense to mean British expatriates in India.

xiii It was generally believed that the Thugs abhorred shedding blood on religious grounds. Although, as the Thugs themselves admitted, this had more to do with the pragmatic objective of escaping detection since blood would have been a tell-tale sign of murder (Parkes 2005, 78). However, as noted earlier, the Thugs did use swords to dispatch their victims occasionally.

${ }^{\text {xiv }}$ In his anonymous 1830 letter to the Calcutta Literary Gazette, Sleeman did write that Thuggee was capable of receiving converts "from all religions and sects" (Sleeman 2009, 181). He obviously had in mind the fact that even the Muslims embraced Thuggee and concomitant Goddess worship. But one wonders whether he would have been at all open to the idea that even Christian Britons could 'convert' to Thuggee.

xv I think Tickell himself implicitly acknowledges this possibility, since he draws our attention to the "propagandist function of Terrorism Studies" (Tickell 2010, 180-181).

\section{References:}

\section{Unpublished Documents:}

Debt to the National Archives of India, New Delhi is hereby acknowledged.

Extract from a Letter from the Honourable Court of Directors, No. 11. (1832, 28 November). National Archives of India, New Delhi. Thagi and Dakaiti Department. B-2, no. 3. 1833. 
List of Thags and Dacoits apprehended between 1829-1836. (1829-36). National Archives of India, New Delhi. Thagi and Dakaiti Department. K-1.

Letter from Captaim H. M. Boddam, Assistant general Superintendent Midnapore, to Major C. Hervey. (1859, 1 July). National Archives of India, New Delhi. Thagi and Dakaiti Department. B-2, no. 27.

\section{Published Works:}

Anonymous. (1866, 9 June). Adventure with a Thug: An Old Officers' Story. Reynold's Miscellany of Romance, General Literature, Science, and Art, 36(939), 388.

Allen, G. and M. Cotes. (n.d.). Kalee's Shrine. Franklin Classics Trade Place. (Original work published in 1886).

Arata, S. D. (1990). The Occidental Tourist: "Dracula" and the Anxiety of Reverse Colonization. Victorian Studies, 33(4), 621 - 645. https://www.jstor.org/stable/ 3827794.

Aubrey, F [F. H. Atkins]. (1910a). The Thug's Legacy. English Illustrated Magazine, 85, 15 - 34.

Aubrey, F [F. H. Atkins]. (1910b). The Thug's Legacy. English Illustrated Magazine, 86, 145 - 154.

Brantlinger, P. (1988). Rule of Darkness: British Literature and Imperialism, 1830-1914. Cornell University Press.

Chakraborty, A. (2020a). Ungendering Thuggee: A Relook at the Female Thugs. Synergy, 16(1), 79 - 91.

Chakraborty, A. (2020b). 'Providential' Campaigns: Intertwining Thuggee and the Sepoy Mutiny in Colonial Fictions. Rupkatha Journal on Interdisciplinary Studies in Humanities, 12(4), 1 - 16. https:// dx.doi.org/10.21659/rupkatha.v12n4.12.

Cumberland, S. C. (n.d.) A Fatal Affinity: A Weird Story. British Library Historical Print Edition. (Original work published in 1889)

Doyle, Sir A. C. (2012). Uncle Jeremy's Household. In Collected Stories of Arthur Conan Doyle (n.p.). http://gutenberg.net.au/ebooks12/ 1200771h.html. (Original work published in 1887)

Guazzo, F. M. (1988). Compendium Maleficarum: The Montague Summers Edition (E. A. Ashwin, Trans.). Dover Publications. (Original work published in 1608)

Jacobson, W. S. (1977). John Jasper and Thuggee. The Modern Language Review, 72(3), 526 - 537. https://www.jstor.org/stable/3725394.

Joseph, L. (2020). Re-Presenting Protestors as Thugs: The Politics of Labelling Dissenting Voices. Rupkatha Journal on Interdisciplinary Studies in Humanities, 12(5), 1 - 6. https://dx.doi.org/10.21659/ rupkatha.v12n5.riocis2n4.

Lloyd, T. (2006). Acting in the "Theatre of Anarchy”: The 'anti-thug Campaign' and Elaborations of Colonial Rule in early Nineteenth-Century India. Edinburgh Papers in South Asian Studies, 19, 2-50.

MacMunn, G. (1933). The Underworld of India. Jarrolds Publishers.

Majeed, J. (1996). Meadows Taylor's Confessions of a Thug: the Anglo-Indian Novel as a Genre in the Making. In B. Moore-Gilbert (Ed.), Writing India 1757-199o: The Literature of British India (pp. 86-109). Manchester University Press.

Majumdar, R. C., Raychaudhuri, H. C. \& Dutta, K. (2010). An Advanced History of India (4 ${ }^{\text {th }}$ ed.). Macmillan Publishers India Limited.

ní Fhlathúin, M. (2001). "That Solitary Englishman”: W. H. Sleeman and the Biography of British India. Victorian Review, 27(1), 69-85. https://www.jstor.org/stable/27793454.

ní Fhlathúin, M. (2004). The Campaign against Thugs in the Bengal Press of the 1830s. Victorian Periodicals Review, 37(2), 124-40. https://www.jstor.org/stable/20084002. 
Parkes, F. (2002). Begums, Thugs and White Mughals. In W. Dalrymple (Ed.). Eland Publishing Limited. (Original work published in 1850)

Rapoport, D. C. (1984). Fear and Trembling: Terrorism in Three Religious Traditions. The American Political Science Review, 78(3), 658 - 77. https://www.jstor.org/stable /1961835.

Siddiqi, Y. (2008). Anxieties of Empire and the Fiction of Intrigue. Columbia University Press.

Singha, R. (1993). 'Providential' Circumstances: The Thuggee Campaign of the 1830 and Legal Innovation. Modern Asian Studies, 27(1), 83-146. http://www.jstor.org/stable/312879.

Sleeman, W.H. (2009). To the Editor of the Calcutta Literary Gazette. In K. A. Wagner (Ed.), Stranglers and Bandits: A Historical Anthology of Thuggee (pp. 174 - 182). Oxford University Press. (Original work published in 1830)

Sleeman, W. H. (1836). Ramaseeana, or A Vocabulary of the Peculiar Language Used by the Thugs. G. H. Huttmann.

Sue, E. (2016) The Wandering Jew. https://www.gutenberg.org/files/3350/3350-h/335o-h.htm\#link2HCHoo35 . (Original work published in 1889)

Taylor, P. M. (n.d.). Confessions of a Thug. British Library Historical Print Edition. (Original work published in 1858 )

Taylor, P. M. (1843). Article VIII. State of Thuggee in India. British and Foreign Review, or, European Quarterly Journal, 15(29), 246 - 91.

Taylor, P. M. (1878). The Story of My Life. William Blackwood and Sons.

Tickell, A. (2010). Excavating Histories of Terror: Thugs, Sovereignty, and the Colonial Sublime. In E. Boehmer and S. Morton (Eds.), Terror and the Postcolonial (pp. 177-201). Wiley Blackwell.

Wagner, K. A. (2014). Thuggee: Banditry and the British in Early Nineteenth-Century India. Primus Books. (Original work published in 2007)

Woerkens, M. V. (2002). The Strangled Traveler: Colonial Imaginings and the Thugs of India (C. Tihanyi, Trans.). The University of Chicago Press.

Dr Ayusman Chakraborty, Assistant Professor of English (West Bengal Education Service), is currently posted at Taki Government College, Taki. North 24 Parganas, West Bengal, India. He is interested in British colonial history, Thuggee, early twentieth century Bengali literature, and nineteenth century British expatriate literature on India. He has written twenty articles till now, which have been published in various national and international academic journals. 